Gorontalo Accounting Journal
https://jurnal.unigo.ac.id/index.php/gaj
Vol. 4, No. 2, October 2021
P-ISSN: 2614-2074, E-ISSN: 2614-2066
Gotonttalo
Nationally Accredited Journal, Decree No.36/E/KPT/2019 Sinta 4

\title{
Determinan Makro Ekonomi Yang Mempengaruhi Nilai Aktiva Bersih Reksa Dana Syariah
}

\author{
Khoirunnisa Azzahra ${ }^{1}$, Baiq Fitri Arianti ${ }^{2}$ \\ 1,2Universitas Pamulang / Jalan Surya Kencana No.1 Pamulang Barat, \\ Tangerang Selatan/Indonesia \\ Email: dosen00880@unpam.ac.id ${ }^{1}$,dosen00862@unpam.ac.id ${ }^{2}$
}

Citation: Azzahra, K. \& Arianti, B. F. (2021). Determinan Makro Ekonomi Yang Mempengaruhi Nilai Aktiva Bersih Reksa Dana Syariah. Gorontalo Accounting Journal 4(2), 146-158. DOI: $\underline{10.32662 / g a j . v 4 i 2.1681}$

\section{Artikel info}

\section{Artikel history:}

Received: 26-07-2021

Revised: 01-10-2021

Accepted: 04-10-2021

\begin{abstract}
The purpose of this study was to determine and analyze macroeconomic factors such as inflation, exchange rates and Indonesian Sharia bank certificates on Net Asset Value. Sources of data obtained from OJK and BI with 5 years of observation, The sampling technique used in this study is non-probability sampling, that is by using saturated sampling with a total sample of 60 data. The method used in this research is descriptive statistical analysis, classical assumption test, multiple linear regression analysis and hypothesis testing. By using the Statistical Package for the Social Science (SPSS) version 22.0 For Windows. The results of this study indicate that inflation has no effect on the value of net assets, while the exchange rate and SBIS partially affect the value of net assets. Simultaneously inflation, exchange rate and SBIS affect the net asset value. Net asset value (NAV) is important in mutual funds, because net asset value is one of the benchmarks in unifying mutual fund performance, the net asset value of equity/unit development mutual funds has increased, and vice versa decreased the value of initial mutual fund net assets/unit participation has decreased.
\end{abstract}

Abstrak. Tujuan penelitian ini adalah untuk mengetahui dan menganalisis faktor makro ekonomi seperti Inflasi, nilai tukar dan sertifikat bank Indonesia Syariah terhadap Nilai Aktiva Bersih (NAB). Sumber data di peroleh dari OJK dan BI dengan 5 tahun pengamatan, Teknik pengambilan sampel yang digunakan dalam penelitian ini adalah non probability sampling, yaitu dengan menggunakan sampling jenuh dengan total sampel 60 data. Metode yang digunakan dalam penelitian ini adalah analisis statistik deskriptif, uji asumsi klasik, analisis regresi linear berganda dan uji hipotesis. Dengan menggunakan program Statistical Package for the Social Science (SPSS) versi 22.0 For Windows. Hasil penelitian menunjukan bahwa inflasi tidak berpengaruh terhadap nilai aktiva bersih, sedang nilai tukar dan SBIS secara parsial berpengaruh terhadap nilai aktiva bersih. Secara simultan inflasi, nilai tukar dan SBIS berpengaruh terhadap nilai aktiva 
Keywords:

Nilai aktiva

bersih; inflasi;

nilai tukar

rupiah bersih. Nilai aktiva bersih (NAB) menjadi penilalian penting
dalam reksa dana, karena nilai aktiva bersih merupakan
salah satu tolak ukur dalam memantau kinerja reksa dana,
maka meningkatnya nilai aktiva bersih reksa dana
mengindikasikan saham/unit penyertaan mengalami
peningkatan, begitu pula sebaliknya menurunnya nilai aktiva
bersih reksa dana mengindikasikan saham/unit penyertaan
mengalami penurunan.

Coresponden author:

Email: dosen00880@unpam.ac.id

\section{Pendahuluan}

Perkembangan pasar modal syariah di Indonesia semakin meningkat hal ini diikuti dengan minat masyarakat Indonesia untuk menggunakan produk investasi syariah. Pasar modal berfungsi sebagai wadah investasi untuk masyarakat. Maka dengan hal tersebut, penerbitan produk-produk investasi di pasar modal menjadi fokus masyarakat yang akan berinvestasi dan sebagai alternatif bagi investor dalam menginvestasikan dananya. Reksa dana merupakan salah satu bentuk dari investasi. Reksa Dana merupakan suatu media investasi yang mempunyai tujuan utama untuk membantu dan memobilisasi pemodal kecil dan individual melakukan investasi di pasar modal. Menurut Asri Sitompul (dalam Tania 2016 :15) menjelaskan bahwa reksa dana dapat memberikan kemungkinan kepada pemodal kecil untuk memiliki bagian dari surat berharga yang mungkin tidak dapat dimilikinya dengan instrumen investasi langsung pada surat berharga tersebut. Melalui Reksa Dana pemodal dibantu oleh sebuah tim manajemen atau wakil manajer investasi untuk mengelola investasinya. Manajer investasi ini melakukan tugas menganalisa surat-surat berharga di pasar uang dan pasar modal serta memilih surat berharga yang sesuai dengan tujuan yang ingin dicapai oleh pemodal

Reksa dana Syariah merupakan salah satu instrumen investasi, yang memiliki kriteria yang berbeda dengan reksa dana konvensional pada umumnya. Reksa dana syariah adalah investasi yang menarik minat masyarakat dalam berinvestasi sesuai dengan prinsip syariah. Dalam Al Qur'an surat al Imron ayat 130-131 Allah berfirman, yang artinya: "Hai orang-orang yang beriman, janganlah kamu memakan riba dengan berlipat ganda dan bertakwalah kepada Allah agar kamu beruntung. Dan peliharalah dirimu dari api neraka, yang disediakan bagi orang-orang kafir". Ayat tersebut menerangkan tentang larangan memakan riba.

Perkembangan reksa dana syariah di Indonesia dari tahun 2015 sampai dengan tahun 2019 dapat dilihat pada gambar 1 . 


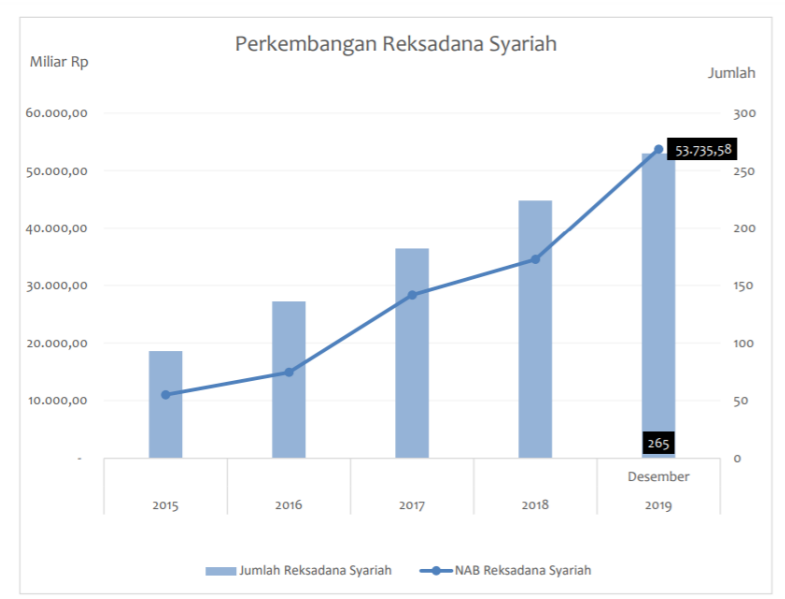

Gambar1. Perkembangan Reksa dana Syariah

Dilihat dari gambar grafik bahwa reksa dana syariah di Indonesia mengalami kenaikan dari tahun ke tahunnya namun pada tahun 2017 sampai dengan 2018 mengalami kenaikan yang tidak signifikan seperti pada tahun-tahun sebelumnya hal ini sejalan dengan fenonema yang terkuak pada tahun 2019 sebanyak 37 perusahaan manajer investasi diberhentikan sementara atau suspen oleh Otorisasi Jasa Keuangan. Hal ini dilakukan oleh OJK dalam rangka pengawasan pasar modal yang dipicu oleh Minna Padi Aset Manajemen (MPAM) yang mengelola salah satu reksa dana syariah yang sampai oktober 2020 kasusnya belum terselesaikan OJK membubarkan reksa dana Minna Padi. berdasarkan Peraturan OJK Nomor 23/POJK.04/2016 salah satu penyebab terjadinya pembubaran yaitu memiliki total nilai aktiva bersih reksa dana kurang dari Rp 10 miliar selama 120 hari bursa berturut-turut, dalam kasus ini tentunya berimbas kepada kerugian yang di alami oleh para investor, kurangnya pemahaman para investor dan manajer investasi terhadap nilai aktiva bersih mengakibatkan kerugian. Nilai aktiva bersih menjadi penilalian penting dalam reksa dana, karena nilai aktiva bersih merupakan salah satu tolak ukur dalam memantau kinerja reksa dana, dengan meningkatnya nilai aktiva bersih reksa dana untuk mengindikasikan saham/unit penyertaan mengalami peningkatan, begitu pula sebaliknya menurunnya nilai aktiva bersih reksa dana mengindikasikan saham/unit penyertaan mengalami penurunan.

Nilai aktiva bersih menjadi salah satu faktor yang mendasari perkembangan Reksa dana Syariah. Maka, untuk mengembalikan kepercayaan investor diharapkan manager investasi dapat mengelola dengan sebaik mungkin reksa dana syariah sehingga dapat mencerminkan nilai aktiva bersih yang tinggi dan para inverstor dapat cermat memperhatikan perkembangan NAB guna mengontrol investasinya. Terdapat factor makro ekonomi yang diduga dapat mempengaruhi NAB reksa dana Syariah diantaranya yaitu inflasi, nilai tukar rupiah, dan sertifikat bank Indonesia syariah (SBIS).

Selanjutnya penelitian mengenai nilai aktiva bersih reksa dana Syariah sudah banyak dilakukan namun adanya ketidak konsistenan pada hasil penelitian terdahulu terkait faktor-faktor yang mempengaruhi nilai aktiva bersih menjadi objek yang menarik dan penting untuk diteliti. Seperti pada hasil penelitian yang dilakukan oleh Evinovita (2015) bahwa inflasi berpengaruh terhadap nilai aktiva bersih sedangkan menurut hasil penelitian yang dilakukan oleh Prasetyo D (2019) bahwa inflasi tidak berpengaruh, dengan adanya ketidak konsistenan hasil penelitian peneliti tertarik untuk melakukan penelitian ulang dengan menambah periode penelitian dan variable sertifikat bank Indonesia syariah. Dengan adanya 
penelitian ini diharapkan dapat mengetahui faktor-faktor yang mempengaruhi nilai aktiva bersih sehingga dapat menjadi tolak ukur bagi para stake holder dalam mengambil keputusan dalam investasi reksa dana Syariah

Berdasarkan latar belakang yang telah diuraikan, maka rumusan masalah dalam penelitian ini adalah 1) apakah inflasi berpengaruh terhadap nilai aktiva bersih. 2) apakah nilai tukar rupiah berpengaruh terhadap nilai aktiva bersih. 3) apakah sertifikat bank Indonesia Syariah berpengaruh terhadap nilai aktiva bersih. 4). Apakah inflasi, nilai tukar rupiah, dan sertifikat bank Indonesia syariah secara simultan berpengaruh terhadap nilai aktiva bersih.

\section{Reksa Dana Syariah}

Reksa Dana Syariah merupakan salah satu investasi syariah yang berkembang di Indonesia. Mengacu kepada peraturan perundang - undangan No. 8 Tahun 1995 tentang pasar modal, reksa dana adalah wadah yang dipergunakan untuk menghimpun dana dari masyarakat pemodal untuk selanjutnya diinvestasikan dalam portofolio efek oleh manajer investasi. Dapat disimpulkan bahwa reksa dana merupakan salah satu portofolio aset keuangan yang terdiversifikasi, tercatat sebagai perusahaan investasi yang terbuka, yang sahamnya dapat di perjual belikan kepada masyarakat dengan harga penawaran dan penarikannya pada harga nilai aktiva bersihnya.

\section{Pengaruh Inflasi Terhadap Nilai Aktiva Bersih Reksa Dana Syariah}

Terjadinya inflasi menyebabkan menurunnya daya beli uang masyarakat secara umum, karena saat inflasi tingkat pendapatan riil masyarakat akan mengalami penurunan. Fluktuasi laju inflasi menunjukkan ketidakstabilan pada harga Masyarakat akan lebih senang memegang uang dalam bentuk kas, dari pada diinvestasikan pada kondisi yang tidak pasti akibat fluktuasi laju inflasi. Pendapat ini didukung oleh penelitian Evinovita et al (2015 :108) dalam penelitiannya menyatakan bahwa variabel inflasi secara parsial berpengaruh negatif terhadap NAB. Berdasarkan uraian tersebut dapat dirumuskan hipotesis pertama yaitu:

$\mathbf{H}_{\mathbf{1}}$ : inflasi berpengaruh terhadap nilai aktiva bersih (NAB).

\section{Pengaruh Nilai Tukar Rupiah Terhadap Nilai Aktiva Bersih Reksa Dana Syariah}

Menurut Sadono Sukirno dalam (Prasetyo et al 2019:138) menyatakan bahwa kurs valuta asing atau kurs mata uang asing menunjukan harga atau nilai mata uang suatu negara dinyatakan dalam nilai mata uang negara lain. Kurs valuta asing dapat juga didefinisikan sebagai jumlah uang domestik yang dibutuhkan, yaitu banyaknya rupiah yang dibutuhkan, untuk memperoleh satu unit mata uang asing. Pendapat tersebut didukung oleh penelitian Prasetyo et al (2019 :149) dalam penelitiannya menyatakan bahwa nilai tukar rupiah berpengaruh terhadap nilai aktiva bersih reksa dana syariah. Berdasarkan uraian tersebut dapat dirumuskan hipotesis kedua yaitu:

$\mathbf{H}_{2}$ : nilai tukar rupiah berpengaruh terhadap nilai aktiva bersih (NAB).

\section{Pengaruh Sertifikat Bank Indonesia Syariah Terhadap Nilai Aktiva Bersih (NAB) Reksa Dana Syariah}

Menurut Peraturan Bank Indonesia Nomor: 10/11/PBI/2008, Sertifikat Bank Indonesia Syariah yang selanjutnya disebut sebagai SBIS adalah surat berharga berdasarkan prinsip syariah berjangka waktu pendek dalam mata uang Rupiah yang diterbitkan oleh Bank Indonesia. Sertifikat bank Indonesia syariah merupakan surat berharga yang diterbitkan oleh bank Indonesia sebagai salah satu instrument operasi pasar terbuka untuk mengendalikan moneter sesuai dengan prinsip syariah. Sertifikat bank Indonesia syariah layaknya sinyal positif bagi manajer investasi dalam mengelola dana investasi yang dititipkan investor dengan harapan terjadinya peningkatan return bagi para investor, maka hal ini menyebabkan nilai aktiva bersih meningkat. Pendapat tersebut didukung oleh 
penelitian Pratiwi ivana et al (2020:108) dalam penelitiannya menyatakan bahwa sertifikat bank sertifikat bank indoensia syariah (SBIS) berpengaruh terhadap NAB. Berdasarkan uraian diatas dapat dirumuskan hipotesis keempat yaitu:

$\mathbf{H}_{3}$ : sertifikat bank sertifikat bank indoensia syariah (SBIS) berpengaruh terhadap nilai aktiva bersih (NAB) reksa dana syariah.

\section{Metode Penelitian}

Metode yang digunakan dalam penelitian ini adalah analisis statistik deskriptif. Jenis data yang digunakan yakni data sekunder berupa lapiran statistik reksa dana syariah yang telah dipublikasikan dan di akses di ojk.go.id. Populasi dalam penelitian ini adalah seluruh Reksa dana Syariah yang terdaftar di OJK dan aktif selama periode Januari 2015 - Desember 2019. Penentuan jumlah sampel dalam penelitian ini adalah dengan metode sampel jenuh diperoleh sebayak 60 data.

Tabel 1. Operasional variable penelitian

\begin{tabular}{|c|c|c|}
\hline Variabel & Definisi & Alat pengukuran \\
\hline $\begin{array}{c}\text { Inflasi } \\
\left(\mathrm{X}_{1}\right)\end{array}$ & $\begin{array}{l}\text { Tingkat inflasi diukur dengan } \\
\text { tingkat harga secara umum yaitu } \\
\text { Indeks Indeks Harga Produsen, } \\
\text { Harga Konsumen, implicit gross } \\
\text { domestic product deflator yang } \\
\text { mengukur rata-rata barang } \\
\text { tertimbang secara keseluruhan } \\
\text { dengan kuantitas barang-barang } \\
\text { yang betul-betul dibeli. }\end{array}$ & Inflasi $=\frac{(\mathrm{IHKt}-\mathrm{IHKt}-1) \times 100 \%}{\mathrm{IHKt}^{-1}}$ \\
\hline $\begin{array}{l}\text { Nilai tukar } \\
\text { rupiah } \\
\left(\mathrm{X}_{2}\right)\end{array}$ & $\begin{array}{l}\text { Kurs mata uang asing atau nilai } \\
\text { tukar valuta asing yaitu nilai } \\
\text { mata uang suatu negara atau } \\
\text { harga yang dinyatakan dalam } \\
\text { mata uang negara lain. Kurs } \\
\text { valuta asing juga dapat } \\
\text { didefinisikan sebagai total uang } \\
\text { domestik (rupiah) yang } \\
\text { dibutuhkan untuk memperoleh } \\
\text { satu unit mata uang asing }\end{array}$ & $\begin{array}{l}\text { Besarnya nilai kurs pada } \\
\text { penutupan perdagangan mata } \\
\text { uang/valuta tiap bulan dalam } \\
\text { satuan Rupiah. }\end{array}$ \\
\hline $\begin{array}{l}\text { Sertifikat } \\
\text { bank } \\
\text { Indonesia } \\
\text { syariah } \\
\text { (SBSI) } \\
\left(\mathrm{X}_{3}\right)\end{array}$ & $\begin{array}{l}\text { Sertifikat bank Indonesia syariah } \\
\text { (SBIS) didefinisikan sebagai surat } \\
\text { berharga yang berlandaskan } \\
\text { prinsip - prinsip syariah yang } \\
\text { berjangka waktu pendek dalam } \\
\text { bentuk mata uang rupiah yang } \\
\text { diterbitkan oleh bank Indonesia. }\end{array}$ & $\begin{array}{c}\text { SBIS }= \\
\text { (nilai nominal investasi } \mathrm{x} \\
\text { tingkat realisasi imbalan } \\
\text { simpanan investasi x jangka } \\
\text { waktu investasi } \mathrm{x} \text { nisbah) }: 360\end{array}$ \\
\hline
\end{tabular}




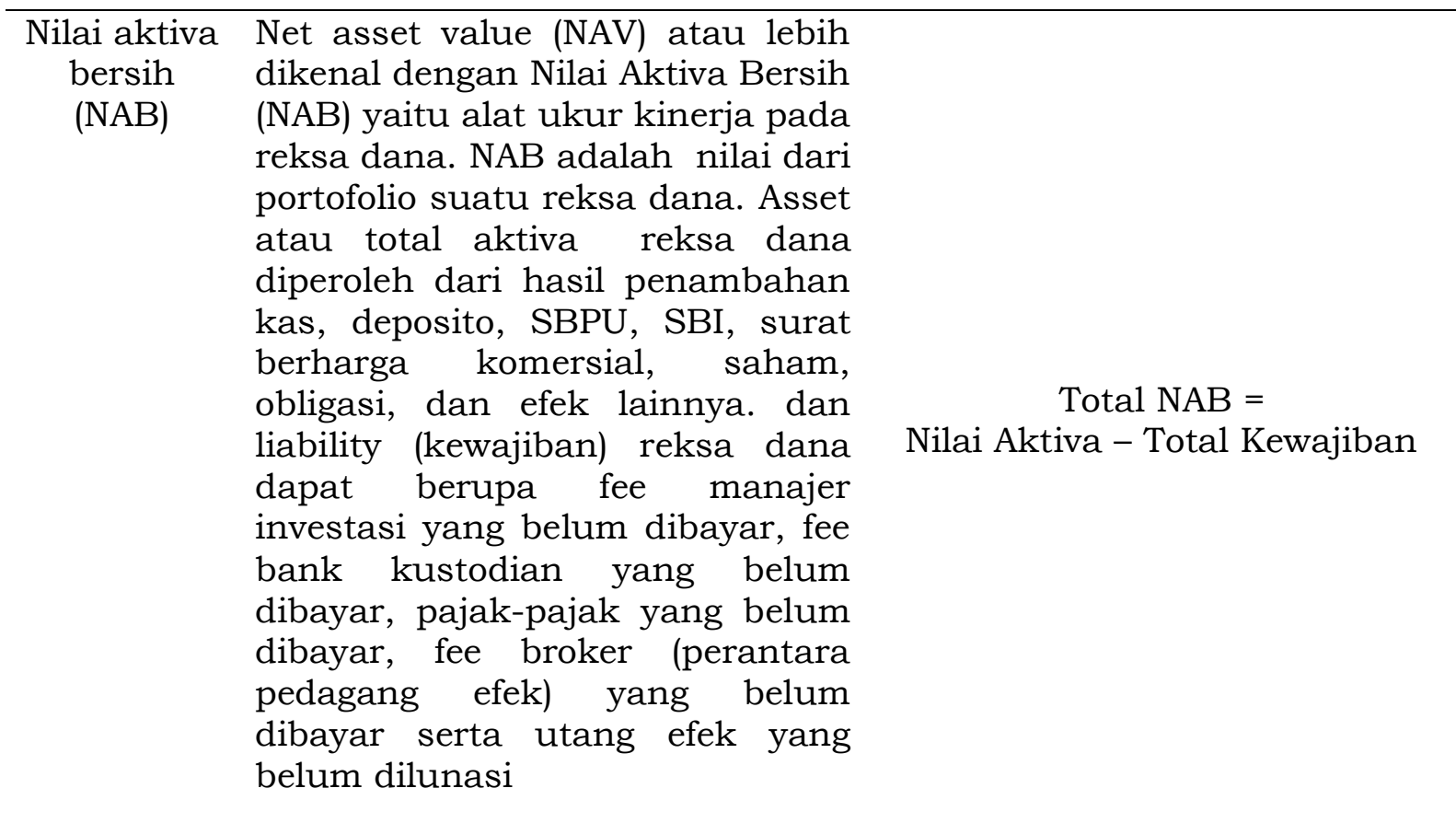

\section{Hasil Dan Pembahasan}

\section{Hasil analisis}

Berikut ini merupakan hasil dari pengujian normalitas, uji multikolonieritas, uji heteroskedastisitas serta uji autokorelasi:

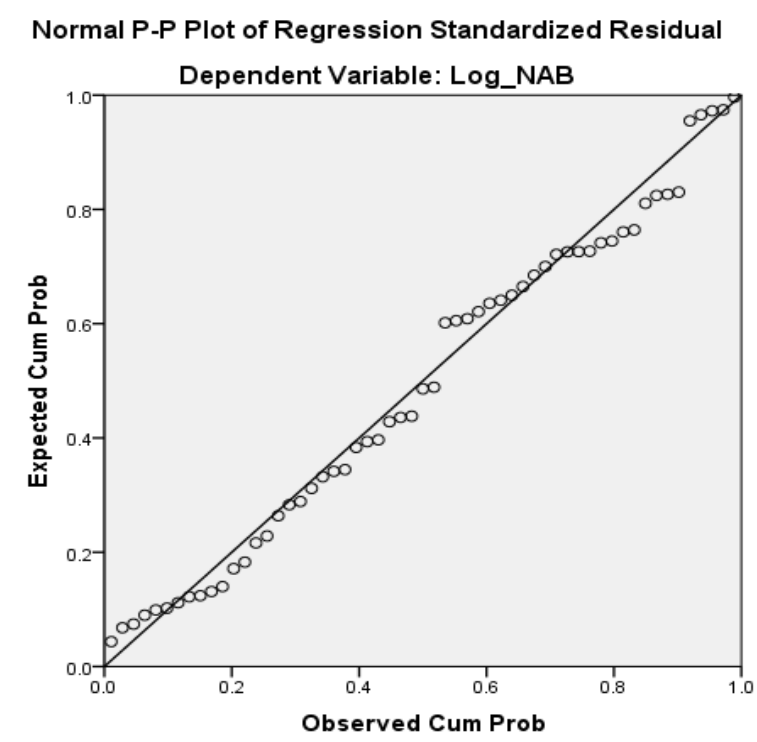

Gambar 2. Normal P-P Plot

Sumber: data diolah program SPSS 22.0 (2021)

Berdasarkan gambar 2 grafik P-P Plot memperlihatkan titik-titik mengikuti garis diagonal, maka data dalam penelitian ini berdistribusi normal. Selanjutnya untuk hasil uji multikolonieritas dijelaskan pada tabel 2 berikut ini: 
Tabel 2. Uji Multikolonieritas Coefficients $^{\mathrm{a}}$

\begin{tabular}{llll}
\hline & & \multicolumn{2}{c}{ Collinearity Statistics } \\
Model & Tolerance & VIF \\
\hline $1 \quad$ (Constant) & & 1.900 \\
& Log_Inflasi & .526 & 1.439 \\
& Log_nilai_tukar & .695 & 1.539 \\
Log_SBIS & .650 & .605 \\
\hline
\end{tabular}

a. Dependent Variable: Log_NAB

Sumber: data diolah program SPSS 22.0 (2021)

Pada tabel 2 dapat dijelaskan bawha pada kolom collinearity statistics nilai inflasi mempunyai tolerance sebesar $0,526<10$ dan nilai VIF sebesar 1,900 > 0,10. Maka dari hasil tersebut dapat diketahui bahwa inflasi tidak mengalami gejala multikolonieritas.

Variabel nilai tukar rupiah dilihat pada kolom collinearity statistics nilai dari nilai tukar rupiah mempunyai nilai tolerance sebesar 0,695 < 10 dan nilai VIF sebesar 1,439>0,10. Maka dari hasil tersebut dapat diketahui bahwa nilai tukar rupiah tidak mengalami gejala multikolonieritas.

Variabel (sertifikat bank Indonesia syariah) SBIS dapat dilihat pada kolom collinearity statistics nilai dari SBIS mempunyai nilai tolerance sebesar 0,650<10 dan nilai VIF 1,539 > 0,10. Maka dari hasil tersebur dapat diketahui bahwa SBIS tidak mengalami gejala multikolonieritas.

Untuk pengujian heteroskedastisitas dalam penelitian ini dilakukan dengan grafik scatterplot. Hasil pengujian yang diperoleh sebagai berikut:

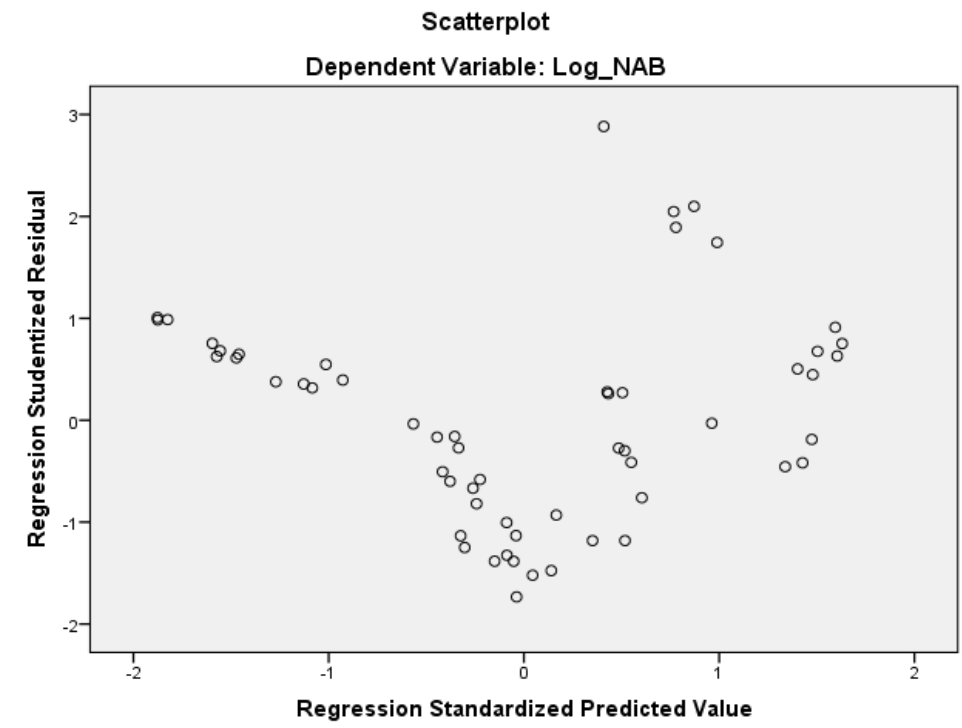

Gambar 3. Scatterplot

Sumber: data diolah program SPSS 22.0 (2021)

Berdasarkan gambar 3 menunjukan bahwa titik-titik data menyebar secara tidak beraturan diatas maupun dibawah angka 0 pada sumbu regression studentized residual dan penyebaran titik tidak membentuk pola. Maka berdasarkan uji heteroskedastisitas menggunakan grafik dinyatakan tidak 
mengalami gejala heteroskedastisitas. Selanjutnya untuk uji autokorelasi dapat dilihat pada tabel berikut ini:

Tabel 3.Uji Autokorelasi Model Summaryb

\begin{tabular}{llrrrr}
\hline Model & $\mathrm{R}$ & $\begin{array}{c}\mathrm{R} \\
\text { Square }\end{array}$ & $\begin{array}{c}\text { Adjusted R } \\
\text { Square }\end{array}$ & $\begin{array}{c}\text { Std. Error of } \\
\text { the Estimate }\end{array}$ & Durbin-Watson \\
\hline 1 & $.834^{a}$ & .696 & .679 & .11325 & 1.673 \\
\hline
\end{tabular}

a. Predictors: (Constant), Log_SBIS, Log_nilai_tukar, Log_Inflasi

b. Dependent Variable: Log_NAB

Sumber: data diolah program SPSS 22.0 (2021)

Tabel 3 memberikan hasil bahwa nilai Durbin Watson yang diperoleh dari hasil regresi sebesar 1,673. Hal ini menunjukan bahwa angka DW terdapat diantara $-2<1,673<+2$ yang artinya tidak ada autokorelasi dalam penelitian ini.

\section{Analisis Regresi Linear Berganda} berikut:

Untuk mengetahui bentuk umum persamaan regresi linear berganda sebagai

Tabel 4. Uji Regresi Linear Berganda

Coefficients ${ }^{a}$

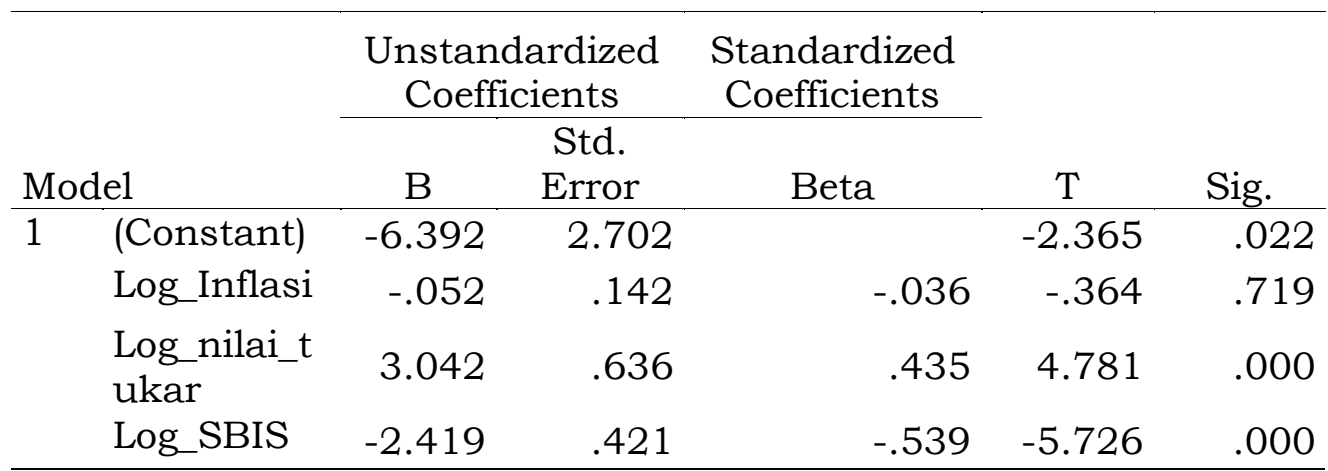

a. Dependent Variable: Log_NAB

Sumber: data diolah program SPSS 22.0 (2021)

Persamaan regresi dalam penelitian ini adalah:

$\mathrm{Y}=\mathrm{a}+\mathrm{B}_{1} \mathrm{X}_{1}+\mathrm{B}_{2} \mathrm{X}_{2}+\mathrm{B}_{3} \mathrm{X}_{3}+\mathrm{e}$

Sehingga hasil analisis regresi yang diperoleh yaitu:

Nilai aktiva bersih $=-6,392+-0,052$ (inflasi) $+3,042$ (nilai tukar rupiah) + 2,419 (SBIS) + e

Berdasarkan hasil perhitungan, maka hasil koefisien regresinya dapat disimpulkan sebagai berikut:

1. Nilai konstanta sebesar -6,392 dapat diartikan apabila semua variabel bebas (inflasi, nilai tukar rupiah, dan SBIS) di anggap konstan atau tidak mengalami perubahan, maka jumlah nilai aktiva bersih sebesar -6,392. Disini konstanta $-6,392$ berarti mempunyai nilai negatif. Konstanta negatif artinya terjadi penurunan pada jumlah nilai aktiva bersih sebesar $-6,392$.

2. Nilai koefisien inflasi $\left(\mathrm{X}_{1}\right)$ sebesar $-0,052$ menyatakan bahwa setiap kenaikan $1 \%$ nilai pada variabel inflasi, maka nilai aktiva bersih $(\mathrm{Y})$ akan mengalami penurunan sebesar -0,052. Nilai koefesien negatif, yang artinya terjado hubungan negarif antara inflasi dengan nilai aktiva bersih.

3. Nilai koefisien nilai tukar rupiah $\left(\mathrm{X}_{2}\right)$ sebesar 3,042 menunjukan bahwa setiap kenaikan $1 \%$ nilai pada variabele nilai tukar rupiah, maka akan mengalami peningkatan sebesar 3,042 pada nilai aktiva bersih (Y). 
4. Nilai koefisien sertifikat bank Indonesia syariah (SBIS) $\left(\mathrm{X}_{3}\right)$ sebesar $-2,419$ menunjukan bahwa setiap kenaikan $1 \%$ nilai pada variabel SBIS, maka Koefisien Determinasi $\left(\mathbf{R}^{2}\right)$ akan mengalami penurunan sebesar $-2,419$ pada nilai tukar rupiah (Y).

Berikut adalah hasil dari uji koefisien determinasi (Uji $\left.\mathrm{R}^{2}\right)$.

Tabel 5. Uji Koefisien Determinasi (Uji R²) Model Summary

\begin{tabular}{llrrrr}
\hline Model & $\mathrm{R}$ & $\begin{array}{c}\mathrm{R} \\
\text { Square }\end{array}$ & $\begin{array}{c}\text { Adjusted R } \\
\text { Square }\end{array}$ & $\begin{array}{c}\text { Std. Error of } \\
\text { the Estimate }\end{array}$ & Durbin-Watson \\
\hline 1 & $.834^{\mathrm{a}}$ & .696 & .679 & .11325 & 1.673 \\
\hline
\end{tabular}

a. Predictors: (Constant), Log_SBIS, Log_nilai_tukar, Log_Inflasi

b. Dependent Variable: Log_NAB

Sumber: data diolah program SPSS 22.0 (2021)

Berdasarkan pada tabel 5 menunjukan bahwa pengaruh dari variabel bebas (inflasi, nilai tukar rupiah, dan SBIS) terhadap variabel terikat (nilai aktiva bersih) memperoleh hasil koefisien determinasi (Adjuster $R$ Square) sebesar 0,679 atau $67,9 \%$ yang berarti bahwa variabel terikat yaitu nilai aktiva bersih dapat dijelaskan sebesar $67,9 \%$ oleh variabel bebas inflasi, nilai tukar rupiah dan SBIS. Sedangkan sisanya $32,1 \%$ dijelaskan oleh variabel lain yang tidak ada atau diluar penelitian ini.

\section{Uji F (Simultan)}

Berikut ini merupakan hasil uji F :

Tabel 6 Hasil Uji F (Uji Simultan)

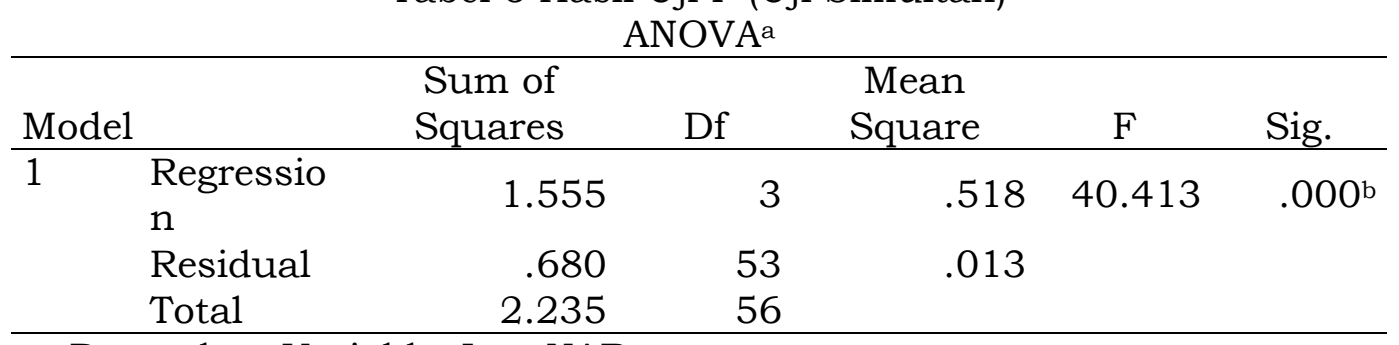

a. Dependent Variable: Log_NAB

b. Predictors: (Constant), Log_SBIS, Log_nilai_tukar, Log_Inflasi

Sumber: data diolah program SPSS 22.0 (2021)

Data uji $\mathrm{F}$, menunjukan bahwa $\mathrm{F}_{\text {hitung }}$ sebesar 40,413 dengan nilai signifikan $0,000^{\mathrm{b}}$. sedangkan untuk mencari $\mathrm{F}_{\text {tabel }}$ dengan jumlah sampel $(\mathrm{n})=60$, jumlah variabel $(\mathrm{k})=4$, taraf signifkan $a=0,05$; df1 $=\mathrm{k}-1(4-1=3)$ dan df $2=\mathrm{n}-\mathrm{k}(60-4=$ 56) diperoleh nilai $F_{\text {tabel }}$ sebesar 2,77 sehingga $F_{\text {hitung }} 40,413>F_{\text {tabel }} 2,77$ dan secara sistematik diperoleh nilai signifikan $0,000^{\mathrm{b}}$. karena nilai signifikan $0,000<$ taraf signifikan 0,05 maka dapat disimpukan $\mathrm{H}_{1}$ diterima. Hal ini menunjukan bahwa Inflasi, Nilai Tukar Rupiah, dan SBIS secara simultan berpengaruh signifikan terhadap Nilai Aktiva Bersih Reksa dana Syariah.

\section{Uji t (Parsial)}

Berikut ini merupakan hasil uji t : 
Tabel 7. Hasil Uji t (Uji Parsial) Coefficients $^{\mathrm{a}}$

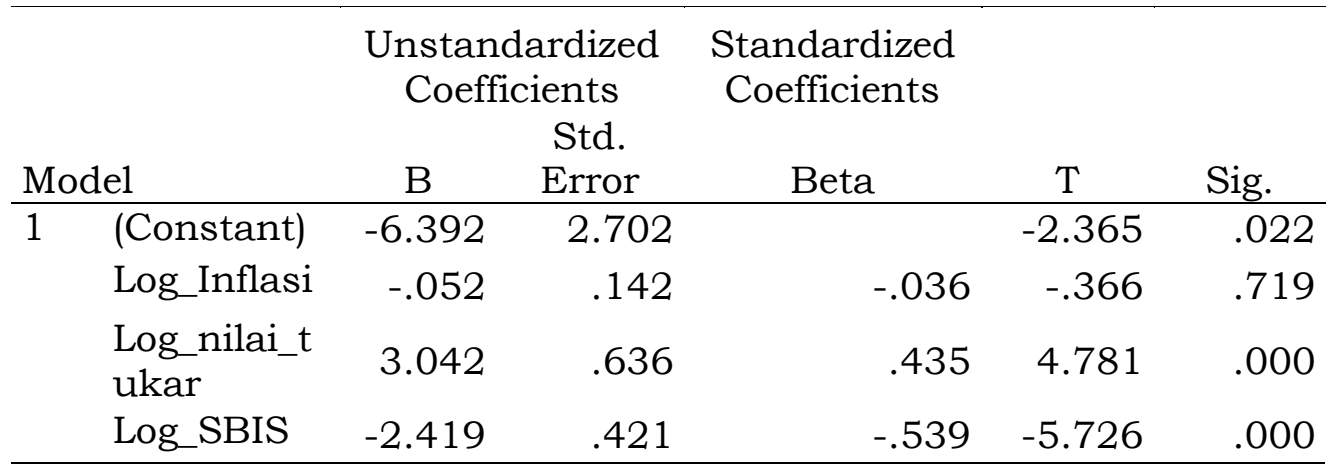

a. Dependent Variable: Log_NAB

Sumber: data diolah program SPSS 22.0 (2021)

Untuk mencari $t_{\text {tabel }}$ yaitu $\mathrm{df}=\mathrm{n}-\mathrm{k}-1(60-3-1=56)$ dan $\operatorname{Pr}=0,050$ yaitu 1,67252. Sehingga dari hasil uji t (parsial) pada tabel 4. Diatas dapat dijelaskan sebagai berikut:

Inflasi memiliki nilai thitung sebesar -0,366 dimana nilai $-0,366<1,67252$ dan nilai signifikan sebesar 0,719 dimana 0,719>0,05 maka dapat disimpulkan $\mathrm{H}_{2}$ ditolak yang artinya inflasi tidak berpengaruh terhadap nilai aktiva bersih reksa dana syariah.

Nilai tukar rupiah memiliki nilai $t_{\text {hitung }}$ sebesar 4,781 dimana 4,781 $>1,67525$ dan nilai signifikan sebesar 0,000 dimana 0,000 < 0,05. Maka dapat disimpulkan $\mathrm{H}_{3}$ diterima yang artinya nilai tukar rupiah berpengaruh signifikan terhadap nilai aktiva bersih reksa dana syariah.

Sertifikat bank Indonesia syariah (SBIS) memiliki thitung sebesar $-5,726$ dimana $-5,726>1,67525$ dan nilai signifikan sebesar 0,000 dimana 0,000 < 0,05. Maka dapat disimpulkan $\mathrm{H}_{4}$ diterima yang artinya sertifikat bank Indonesia syariah (SBIS) berpengaruh signifikan terhadap nilai aktiva bersih reksa dana Syariah

\section{Pembahasan}

\section{Pengaruh Inflasi terhadap Nilai Aktiva Bersih}

Berdasarkan hasil uji $t$, variabel inflasi memiliki nilai $t_{\text {hitung }}<t_{\text {tabel }}(-0,366<$ $1,67252)$, nilai signifikan $p$-value $>a(0,719>0,05)$. Dapat disimpulkan bahwa inflasi secara parsial tidak berpengaruh terhadap nilai aktiva bersih reksa dana syariah.

Secara umum inflasi merupakan kenaikan harga yang terjadi secara terus menerus. Perubahan inflasi dalam kurun waktu yang singkat tidak langsung mendapat respon dari pasar, dengan lambatnya respon pasar maka tidak mengalami perubahan terhadap nilai aktiva bersih tidak langsung terjadi, dikarenakan dibutuhkan jangka waktu antara perubahan inflasi dan respon pasar. Karena tingkat inflasi selama periode penelitian masih dibawah $10 \%$ maka harga barang-barang tidak bergerak signifikan dan meningkat secara derastis hal ini tidak dapat mempengaruhi terhadap nilai aktiva bersih.

Penelitian ini memberikan hasil yang sejalan dengan penelitian yang dilakukan oleh Prasetyo et al (2019) dalam penelitian menyatakan bahwa variabel inflasi tidak berpengaruh secara signifikan terhadap nilai aktiva bersih reksa dana syariah.

Pengaruh Nilai Tukar Rupiah Terhadap Nilai Aktiva Bersih

Berdasarkan uji $t$, variabel nilai tukar rupiah memiliki nilai $t_{\text {hitung }}>t_{\text {tabel }}$ $(4,781>1,67525)$ dengan nilai signifikan $p$-value $<0,05(0,000<0,05)$ dapat 
disimpulkan bahwa secara parsial nilai tukar rupiah berpengaruh signifikan terhadap nilai aktiva bersih reksa dana syariah.

Penelitian ini menunjukan hasil nilai tukar rupiah berpengaruh positif signifikan terhadap nilai aktiva bersih reksa dana syariah. Hal ini dikarenakan Setiap penguatan kurs rupiah yang ditandai dengan menurunnya nilai tukar rupiah terhadap USD pada tahun 2019 hal ini tentunya dapat meningkatkan nilai aktiva bersih reksa dana syariah yang ada di Indonesia. Selain itu para investor menilai kondisi makroekonomi sedang dalam kondisi baik sehingga membuat kepercayaan para investor meningkat, dengan meningkatnya kepercayaan investor maka investor tertarik berinvestasi dalam pasar modal dengan harapan mendapatkan return yang tinggi, karena reksa dana merupakan salah satu instrumemn dalam pasar modal yang berbasis syariah, tentu kondisi tersebut akan berdampak baik terhadap reksa dana.

Hasil penelitian ini sejalan dengan penelitian yang dilakukan Prasetyo et al (2019) yang menyatakan bahwa variabel nilai tukar rupiah berpengaruh signifkan terhadap nilai aktiva bersih reksa dana syariah.

\section{Pengaruh Sertifikat Bank Indonesia Syariah terhadap Nilai Aktiva Bersih}

Berdasarkan uji t variabel sertifikat bank Indonesia syariah (SBIS) memiliki nilai $t_{\text {hitung }}>t_{\text {tabel }}(-5,726>1,67525)$ dengan nilai signifikan $p$-value $<0,05(0,000<$ 0,05) dapat disimpulkan bahwa secara parsial sertifikat bank Indonesia syariah (SBIS) berpengaruh negatif terhadap nilai aktiva bersih reksa dana syariah.

Sertifikat Bank Indonesia Syariah (SBIS) menunjukan hubungan negatif dengan nilai aktiva bersih (NAB), jika sertifikat bank Indonesia syariah (SBIS) menurun maka Nilai aktiva bersih (NAB) akan meningkat. Dengan turunnya tingkat sertifikat bank Indonesia syariah (SBIS) akan mempengaruhi iklim investasi di pasar modal dan pasar uang syariah, dan juga dapat menurunkan tingkat nisbah simpanan dan deposito mudharabah, maka para investor akan berpindah ke instrument yang memberikan tingkat bagi hasil yang lebih tinggi di pasar modal yaitu reksa dana syariah, dan hal tersebut akan meingkatkan nilai aktiva bersih dari reksa dana syariah.

Hasil penelitian ini sejalan dengan penelitian Pratiwi ivana et al (2020) yang mengatakan bahwa sertifikat bank Indonesia syariah (SBIS) berpengaruh negative terhadap nilai aktiva bersih reksa dana syariah. Hal tersebut dikarenakan kenaikan sertifikat bank Indonesia syariah (SBIS) membuat para investor beralih ke investasi yang memiliki risiko rendah namun tetap memberikan keuntungan yang menjanjikan, sehingga indeks pasar modal akan mengalami penurunan yang mengakibatkan nilai aktiva bersih reksa dana juga akan mengalami penurunan.

\section{Kesimpulan Dan Saran Kesimpulan}

Berdasarkan hasil analisis dan pembahasan mengenai variabel inflasi, nilai tukar rupiah, dan sertifikat bank indonesia syariah (SBIS) terhadap nilai aktiva bersih reksa dana syariah, dapat diambil kesimpulan bahwa inflasi secara parsial tidak berpengaruh terhadap nilai aktiva bersih reksa dana syariah hal ini disebabkan karena tingkat inflasi kurang dari 10\% pertahunnya sehingga tidak menarik respon investor karena inflasi ini masih dalam kategori inflasi ringan, Nilai tukar rupiah secara parsial berpengaruh positif dan signifikan terhadap nilai aktiva bersih reksa dana syariah hal ini disebabkan oleh adanya penguatan kurs rupiah yang ditandai dengan menurunnya nilai tukar rupiah terhadap USD pada tahun 2019, maka hal tersebut akan meningkatkan nilai aktiva bersih reksa dana syariah yang ada di Indonesia. Sertifikat bank Indonesia syariah (SBIS) secara parsial berpengaruh negative dan signifikan terhadap nilai aktiva bersih reksa 
dana syariah hal ini disebabkan oleh turunnya tingkat sertifikat bank Indonesia syariah (SBIS) sehingga mempengaruhi iklim investasi di pasar modal dan pasar uang syariah.

\section{Saran}

Adapun saran yang dapat diajukan penulis setelah melakukan penelitian ini di harapkan manager investasi reksa dana syariah dapat memperhatikan faktor faktor yang mempengaruhi nilai aktiva bersih reksa dana syariah seperti makro ekonomi sehingga dapat meningkatkan total nilai aktiva bersih yang tinggi, dengan nilai aktiva bersih yang tinggi diharapkan dapat mengembalikan kepercayaan investor

Para investor diharapkan dapat dengan cermat memperhatikan nilai aktiva bersih supaya tidak terjadi kerugian investasi dikemudian hari, karena nilai aktiva bersih menjadi penilalian penting dalam reksa dana, karena nilai aktiva bersih merupakan salah satu tolak ukur dalam memantau kinerja reksa dana, maka meningkatnya nilai aktiva bersih reksa dana mengindikasikan saham/unit penyertaan mengalami peningkatan, begitu pula sebaliknya menurunnya nilai aktiva bersih reksa dana mengindikasikan saham/unit penyertaan mengalami penurunan.

\section{Daftar Pustaka}

Asriwahyuni, I. G. (2017). Pengaruh Ukuran dan Umur Pada Kinerja Reksa Dana Saham di Indonesia. E-Jurnal Akuntansi, 21(2), 1460-1487. https://doi.org/10.24843/EJA.2017.v21.i02.p22

Chairani, S. (2020). Pengaruh Nilai Tukar Rupiah (Kurs), Jakarta Islamic Index (JII), Usia Reksa dana, Dan Volume Perdagangan Reksa dana Syariah. Tirtayasa Ekonomika, 15(1), 31-43.

Evinovita, Rahim, A., \& Ishardyatmo, H. (2015). Pengaruh Tingkat Suku Bunga dan Inflasi Terhadap Peningkatan Nilai Aktiva Bersih Reksa Dana Saham. Jurnal Manajemen, 6(2), 101-108.

Gumilang, Y. N. L., \& Herlambang, L. (2017). Faktor-Faktor Yang Mempengaruhi Nilai Aktiva Bersih Reksa dana Manulife Syariah Sektor Amanah. Jurnal Ekonomi Syariah Teori Dan Terapan, 4(2), 117. https://doi.org/10.20473/vol4iss20172pp117-127

Ilyas, M., \& Shofawati, A. (2020). Pengaruh Inflasi, Nilai Tukar Rupiah, Bi Rate Terhadap Nilai Aktiva Bersih Reksa Dana Terproteksi Syariah Periode 20142018 Di Indonesia. Jurnal Ekonomi Syariah Teori Dan Terapan, 6(9), 1830. https://doi.org/10.20473/vol6iss20199pp1830-1839

Lestari, H., \& Hendrawati. (2020). Pengaruh Inflasi, Nilai Tukar Rupiah, dan Jakarta Islamic Index ( JII ) Terhadap Nilai Aktiva Bersih Reksa dana Syariah di Indonesia ( Studi Kasus Pada Otoritas Jasa Keuangan Periode Tahun 20162019). Sekolah Tinggi Ilmu Ekonomi Indonesia, 1-16.

Nandari, H. U. D. R. A. (2017). Pengaruh Inflasi, Kurs Dan Bi Rate Terhadap Nilai Aktiva Bersih (Nab) Reksa dana Syariah Di Indonesia (Periode 2010-2016). AnNisbah: Jurnal Ekonomi Syariah, 4(1), 30-34. https://doi.org/10.21274/an.2017.4.1.51-74

Ojk. (2020). Statistik Reksa Dana Syariah - Desember 2019. Otoritas Jasa Keuangan, $\quad 1.1$ https://www.ojk.go.id/id/kanal/syariah/data-danstatistik/reksa-dana-syariah/Documents/Pages/-Statistik-Reksa-DanaSyariah---Desember-2019/Statistik Reksa Dana Syariah 2019 Desember.pdf

Pariela, M. V. G. (2018). Wanprestasi Manajer Investasi Terhadap Investor Reksa dana. Sasi, 23(2), 129. https://doi.org/10.47268/sasi.v23i2.100

Prasetyo, D., \& Widiyanto. (2019). Pengaruh Inflasi, Nilai Tukar Rupiah, Suku 
Bunga Bank Indonesia, dan Harga Emas Terhadap Nilai Aktiva Bersih Reksa dana Syariah. Konferensi Ilmiah Mahasiswa Unissula (Kimu) 2, 133-153.

Septiana, F., \& Al Arif, M. N. R. (2020). Determinants of Net Asset Value of Islamic Mutual Funds in Indonesia. Al-Amwal: Jurnal Ekonomi Dan Perbankan Syari'ah, 12(1), 1. https://doi.org/10.24235/amwal.v1i1.5443

Tania, A. L. (2016). Analisis reksa dana Syariah dalam konsep Nilai Aktiva Bersih (NAB). Jurnal Al-Imi, 1(1), 15-31.

Waridah, W., \& Mediawati, E. (2016). Analisis Kinerja Reksa dana Syariah. Jurnal Riset Akuntansi Dan Keuangan, 4(2), 1077-1086. https://doi.org/10.17509/jrak.v4i2.4043

Wicaksono, M. P., \& Sampurno, R. D. (2017). Analisis Pengaruh Fund Age, Market Timing Ability, Stock Selection Skill, Portfolio Turnover dan Fund Size Terhadap Kinerja Reksa dana Sayariah Periode 2013 - 2015. Diponegoro Journal of Management, 6(3), 1-11.

Yeny Fitriyani, M. R. R. dan N. A. A. (2020). (2020). Faktor-Faktor Makroekonomi Yang Mempengaruhi. Jurnal Bisnis Dan Ekonomi, 16(1), 610-621. https:/ / www.neliti.com/publications / 14817/analisis-dampak-pembayarannon-tunai-terhadap-jumlah-uang-beredar-di-indonesia 